\title{
Thematic Structure VS. Information Structure in THE ANalysis Of Translation Shifts
}

\begin{abstract}
This paper aims to show that the comparison of the source and target text's information structure should be a prerequisite of and take priority over the analysis of their thematic structure (in the Hallidayan sense). Thus, it is argued that in such analysis the original's distribution of communicative dynamism is a more important consideration that its linear arrangement. The article offers a critical analysis of Munday (1998) and contrasts his approach with the one based on the model developed by the Brno branch of the Prague School. It is also pointed out that the conflict between keeping the original's word order and the distribution of communicative dynamism may often be resolved by means of the strategies for avoiding linear dislocation described by Baker (1992: 167-172). The paper also establishes a hierarchy of priorities that the translator should follow to keep the ST's information structure.
\end{abstract}

\section{Keywords}

Thematic structure; information structure; linear arrangement; communicative dynamism; translation shift; functional sentence perspective

\section{Introduction}

When comparing the information and/or thematic structure of a translation with that of the original, one can choose between two main approaches: the model developed by the Brno branch of the Prague School, and especially Jan Firbas (also referred to as the Functional Sentence Perspective (FSP) approach), or the one based on Michael Halliday's Systemic Functional Linguistics (SFL) (cf. Kim and Mathiessen 2015: 339). The main difference between them is that the FSP 
framework does not equate word order with thematic organization. The linear arrangement is just one the FSP means, along with the contextual and the semantic factors. Taken together, they determine the degree of communicative dynamism (CD) carried by a given element (CD being the "extent to which the sentence element contributes to the development of the communication, to which, as it were, it 'pushes' the communication forward" (Firbas 1966: 240)). Thus, the thematicity or rhematicity of a sentence element is not invariably linked with word order, but depends on the distribution of $\mathrm{CD}$ in the sentence, a distribution governed primarily by the context and then by the element's semantic character and relations (Firbas 1992: 41). By contrast, the SFL approach considers theme to be always the first element of the clause. ${ }^{1}$ Thus, the SFL model separates thematic structure from information structure, unlike the FSP framework, which conflates them (Baker 1992: 121; Fries 1983: 116-117). ${ }^{2}$

Comparing the theme-rheme structure of a source text (ST) and target text (TT) raises the perennial issue of similarity in difference. If $A$ boy came into the room (example from Firbas (1992: 115)) is translated into Polish as Do pokoju wszedt chtopiec [Into the room came a boy], the thematic structure of the TT will be considered different from the ST's in the SFL model, as the thematic boy will become the rhematic chtopiec. Conversely, the TT will be deemed equivalent in terms of FSP in the Firbasian approach as having the same distribution of CD despite the sentence elements being arranged in reverse order. From the latter's viewpoint, the two sentences are equivalent in terms of FSP even though or rather because their linear arrangement is different.

The fact that the FSP model conflates thematic and information structures, while the SFL approach separates them means that it is not possible to compare FSP information structure with SFL thematic structure as they deal with different language systems. It seems, however, that comparison of a source and target text's information structure should be a prerequisite of and take priority over the analysis of their thematic structure (in the SFL sense). The reason is that information structure outranks thematic structure in the hierarchy of language as the significance of new information in a clause for the message it conveys is greater than that of the first element of the clause. Moreover, the category of given and new information is universal, unlike thematic structure, which is language-specific (cf. Halliday 1994: 38).

Accordingly, this paper aims to show the inadequacy of Jeremy Munday's SFL-based attempt at analyzing thematic shifts in translations, which does not take the ST's and TT's information structure into account, and to contrast it with an approach based on the FSP model (Section 2). In Section 3 an analysis is carried out of some examples from an English translation of a Polish short story. Informed by the Firbasian approach, the analysis shows that even though the ST's distribution of CD should take precedence over the linear arrangement, both can often be preserved thanks to some strategies of avoiding linear dislocation described by Baker (1992: 167-172). Their real importance is shown to lie precisely in making it possible to keep the ST's word order and distribution of CD. 


\section{The SFL thematic structure and the FSP information structure analysis of translations}

In his analysis, Munday pays attention to (i) what element is put in sentence-initial position (called "theme position" in the SFL approach), especially (ii) what element becomes the topical theme ("the first element that is a participant, process or circumstance" (Munday 1998: 184)), (iii) whether theme choices are marked and (iv) what the thematic progression of the text is. (Overall, however, these come down to just two criteria: theme position and markedness.) By virtue of (iii) the absence of subject pronouns from Spanish sentences of the type senti un terror tan intenso is treated as a result of ellipsis, which means that when translated as Ifelt a terror so intense, no thematic shift is deemed to have occurred (187-188). As for (i), it appears that this kind of analysis cannot account for the differences in the way FSP operates in Spanish and English as it describes only changes in word order, without looking into the internal communication dynamics. Thus, when Spanish verb-subject (VS) clauses, which cannot be translated as such into English, are rendered by means of different word order, Munday cannot but consider this a shift, for instance, with

(1) Se había precipitado una tormenta de verano

[[There] had rushed across a summer storm $]^{4}(201)$

translated as

(2) A summer storm had broken (201)

However, as regards the information structure of these sentences, both (1) and (2) would be said to implement the Presentation Scale in the FSP model whereby the communication is perspectived toward a context-independent subject which signals the existence or appearance on the scene of a phenomenon to be presented (cf. Firbas 1992: 66). ${ }^{5}$ Thus, the high point of the Spanish and the English sentence is una tormenta de verano and a summer storm respectively. The fact that they feature different word orders is of secondary importance; what matters most is that both are perspectived toward the same element and both are unmarked. (It should be borne in mind that "an order that is natural in one language may not appear to be so in another" (Firbas 1979: 55).)

Munday admits that (1) would sound unusual if the translator had decided to imitate the original's word order and had come up with

(3) There had suddenly brewed up/arrived a summer storm (Munday 1998: 201)

In another example, however, he suggests that the translator should have striven to preserve the ST's linear arrangement. He claims that in 
(4) Entonces entraba Fulvia Flamínea, la cocinera, con la eterna sopa de fideos de aquel verano aborrecible.

[Then used to enter Fulvia Flaminea, the cook, with the eternal vermicelli soup of that abominable summer.] (201)

the focus of the sentence is on the verb entraba and thus on the motion. This emphasis, he argues, is lost in the TT, which runs:

(5) Then the cook, Fulvia Flaminea, came in, carrying the eternal vermicelli soup of that abominable summer. (202)

However, the focus cannot be on entraba since, as Munday himself observes, verbinitial clauses in Spanish are unmarked (188). As a matter of fact, as Baker (1992: 131-2) points out, the importance attached to theme position in the SFL approach is confusing. If rheme is the part of the utterance which contains new information, why then is theme associated with prominence or emphasis? The problem is further compounded by Halliday's vagueness about rheme, which he defines as the "remainder of the message, the part in which the Theme is developed" (Halliday 1994: 37), without making clear where exactly the focus of the message falls.

The question of the supposed emphasis placed on the clause-initial element does not arise in the Firbasian approach, where emphasis is linked with $C D$, whose distribution is not a simple function of word order. Moreover, this theoretical framework provides a detailed description of the non-thematic part of the sentence. All in all, whatever prominence a clause-initial element may have, it will "carry less weight than the actual rheme" (Kirkwood, quoted in Baker 1992: 132), and the rheme of (4) (in the FSP approach) is Fulvia Flaminea, la cocinera.

From the FSP model's viewpoint, both the ST and the TT implement the Combined Scale, realizing the setting, presentation of phenomenon, phenomenon presented, and specification functions. The last of these is performed by the phrase con la eterna sopa de fideos de aquel verano aborrecible in the ST, and by the semiclause carrying the eternal vermicelli soup of that abominable summer in the TT, which become rhemes proper (cf. Firbas 1992: 129). The phenomenon presented is Fulvia Flaminea, la cocinera and the cook, Fulvia Flaminea respectively. Given that the texts are perspectived toward the same element and both are unmarked, there is no reason why, as Munday suggests, the translation should read

(6) Then in would come Fulvia Flaminea, the cook, with the eternal vermicelli soup. (Munday 1998: 202)

This version is not only marked but is also perspectived toward in would come rather than Fulvia Flaminea, the cook, and the latter becomes a context-dependent piece of information. In fact, (6) creates emphasis where it is absent in the $\mathrm{ST}$, making the verb phrase rhematic. Thus, the erroneous assumption about the 
prominence of the ST initial verb leads to a shift in information structure. In terms of the FSP approach, (6) implements the Quality Scale, and the high point of the communication is no longer the arrival on the scene of the cook but a quality (i.e. an action) attributed to her, or, to be more precise, the directionality of the action.

The Combined Scale is also featured in another example adduced by Munday:

(7) y en el curso de la lectura le pasaban por la cara las ráfagas de claridad que irradiaban las palabras escritas

[and in the course of the reading passed over her face flashes of light that were irradiating the written words] (201)

Its translation, in turn, displays the Presentation Scale:

(8) and while she read, flashes of light radiating from the written words passed over her face (202)

Again, both the ST and the TT are perspectived toward the same element, i.e. las ráfagas de claridad and flashes of light radiating from the written words respectively. (The lack of a comma after flashes of light makes rheme proper longer in (8).) As before, the TT is unmarked, just like the ST. Nevertheless, Munday's interpretation of the two sentences is quite different. He claims that the focus of (7) is on the verb pasaban in theme position (oddly enough it is not in theme position). Speaking of all the three ST examples ((1), (4) and (7)), he contends, rather confusingly, that "the prominence and communicative dynamism of material process forms [...] highlight that Spanish is a more 'event-based' language" (Munday 1998: 207) than English. He does not explain, however, why it should matter for thematic structure what types of verbs are chosen as topical themes; besides the English translations also feature material process verbs. Neither does he make it clear what he means by "prominence" and "communicative dynamism". It seems, however, that he does not use the latter term in the sense given to it in the FSP approach since he suggests that the communicative dynamism of an element rises when it is placed in clause-initial position. Now in the FSP approach this is true, with some qualifications, for fronting. As pointed out by Firbas (1992: 125-6), there are two kinds of fronting: that of rhematic and that of thematic elements (obviously in his sense of the terms). However, it is only in the case of rhematic fronting that the sentence is perspectived toward the initial element, although it is true that the initial element in thematic fronting is communicatively more dynamic than the one that follows; for instance in Most of these problems a computer would take in its stride (Firbas' example (1992: 125), quoted after Quirk et al.), most of these problems is diatheme, i.e. it exceeds theme proper (a computer) in CD. ${ }^{6} \mathrm{It}$ is, however, less communicatively dynamic than rheme proper (take in its stride).

Thus, it is evident that Munday's claim about the supposed emphasis placed on Spanish sentence-initial verbs is untenable, since none of his examples features 
rhematic fronting. He argues that ways should be sought of keeping this assumed focus in translation, suggesting that the last Spanish sentence might have been rendered as

(9) and, as she read, there passed over her face flashes of light radiated by the written words (Munday 1998: 202)

or

(10) and, as she read, over her face passed flashes of light radiated by the written words (203)

However, what these versions throw into relief is not the initial verb passed ${ }^{7}$, but the context-independent subject flashes of light radiated by the written words. The difference between (8) on the one hand, and (9) and (10) on the other is that the latter's linear arrangement (from the least to the most communicatively dynamic) reinforces the subject's "consummative communicative function" by putting it in sentence-final position (see Firbas 1992: 62). Thus, (9) and (10) are closer to the original's information structure than (8), but for a different reason than Munday claims (with SFL thematic structure in mind). Nevertheless, they are marked, unlike the ST, which illustrates Firbas' point that "[ $\mathrm{t}]$ wo languages may use the same word order, but the effects produced need not necessarily be the same" (Firbas 1992: 124).

Only on one occasion does Munday refer to information structure in his analysis, but the way he does so indicates that he understands it as a mere sequencing of information, with no regard for the sentence's communication dynamics. Here is the source text sentence and its translation:

(11) y entramos por la galería lateral, donde estaban dos hombres fumando sentados en el suelo junto a una camilla de campaña

[and [we] entered through the side veranda, where were two men smoking seated on the floor next to a stretcher] (Munday 1998: 199)

(12) and [we] went to the side veranda, where two men sat on the floor next to a stretcher and smoked (200)

Munday argues that "[a]s far as the information structure is concerned, the TT highlights smoked as separate and new information at the end of the sentence, giving it a narrative prominence it does not have in the ST". He further claims that "this is the case no matter whether we adopt the Hallidayan approach or the Functional Sentence Perspective linearity principle of rising Communicative Dynamism" (200). Now while it is true that smoked in a separate clause does seem more prominent than in the ST, it is by no means the case that the word 
constitutes the high point of the message in the FSP approach. In fact, both the ST and the TT display the Presentation Scale, being perspectived toward their context-independent subjects, dos hombres and two men respectively. Significantly, the two phrases are not preceded by the definite article, which indicates that they have not yet been introduced into the discourse. The presentation of phenomenon is performed in the ST by estaban fumando, and in the TT by sat in the first clause and smoked in the second. (Interestingly, these verbs are not, strictly speaking, verbs of existence/appearance on the scene, but nevertheless clearly signal it (cf. Firbas 1992: 59-61).) Thus, from the viewpoint of the FSP approach, the communication cannot be perspectived to smoked, which is merely a transitional element. It seems, however, that the translator might have chosen a version that does not place it last in a separate clause but, for instance, have gone for:

(13) where two men sat smoking on the floor next to a stretcher

This seems preferable to Munday's proposed version

(14) where there were two men smoking, sitting on the floor next to a stretcher (Munday 1998: 200)

which follows the original linear arrangement more closely but sounds more stilted. Munday, however, does not comment on the stiltedness, but merely points out that (14) may not have been chosen "because the order of smoking, sitting does not intuitively fit a common TL pattern" (200). As a solution, he suggests changing the word order to sitting, smoking. Be that as it may, Munday's understanding of information structure is different from that of both the FSP and SFL approaches.

Needless to say, the position-bound understanding of theme also informs SFLbased analysis of thematic progression. Interestingly, however, the first to put forward the notion of thematic progression and its different types was Daneš, who understood theme in the FSP sense. Commenting on the formula $\mathrm{T} \rightarrow \mathrm{R}$ (indicating a theme-rheme nexus), he explains that "the order of symbols does not necessarily correspond to the sequence of expressions in a particular sentential utterance based on this formula, since this sequence depends on the interplay of language means employed in FSP" (Daneš 1974: 118). This means that thematic progression is analyzed along different lines in the SFL and FSP approaches; the former examines the links between clause-initial elements in a portion of text; the latter looks at items which may or may not be clause-initial and yet are concatenated on account of carrying the lowest amount of CD and being the text's foundation-laying elements. In fact, Mathesius' definition of theme as "the starting point of the utterance" (quoted in Daneš 1974: 106) concurs with that by Halliday (1994: 37), who speaks about "the point of departure of the message". The question is, however, whether this should be understood in the interpretative or linear sense. 
Munday discusses three examples as part of his analysis of thematic progression, but only one concerns thematic progression as understood by Daneš (1974: 114), who defines it as "the choice and ordering of utterance themes, their mutual concatenation and hierarchy, as well as their relationship to the hyperthemes of the superior text units (such as the paragraph, chapter,...), to the whole text, and to the situation". Thus, Munday compares the distribution of adverbials of time in an ST-TT pair in a string of sentences, and finds that in one of them an adverbial was moved from the end of the sentence toward the beginning in the translation:

(15) Sin embargo, llegó tan puntual como siempre al desayuno del miércoles. (Munday 1998: 205)

[However, [she] arrived as punctual as ever to breakfast on Wednesday.]

(16) Yet on Wednesday she came to breakfast with her customary punctuality. (Munday 1998: 206)

Example (15) concludes a series of sentences beginning with adverbials of time, departing as it does from this pattern. Thus, as Munday points out, (16) displays greater cohesion with the preceding text. He argues, however, that by placing on Wednesday close to sentence-initial position the translation loses "the contrast and surprise value" (206) of the ST as well as its emphasis on the woman's appearance. Again, as in the case of (4), Munday contends that the focus of the original sentence is on the initial verb (llegó) and suggests the same solution of fronting the preposition:

(17) Yet in she came as punctual as ever for breakfast on Wednesday. (206)

Again, his preoccupation with the initial verb causes him to overlook the fact that the real focus of (15) is on the sentence-final specification al desayuno del miércoles and that in (17) the emphasis is shifted away from the final adverbial to the fronted preposition in.

\section{Preserving the ST's CD and linear arrangement}

This part of the paper aims to show that there does not have to be a conflict between preserving the ST's CD and linear arrangement in translation. In fact, both can often be kept up thanks to the four strategies for dealing with linear dislocation in translation described by Baker (1992: 167-172). These include: (i) voice change, (ii) change of verb, (iii) nominalization and (iv) extraposition. Oddly enough, Baker admits that "it is very difficult indeed to find clear examples of any of the above strategies in authentic translations" (171). What the translators 
do, she claims, is to "abandon the thematic organization of the ST in favour of adhering to whatever word-order principles may be operating in the TL" (171). (Incidentally, this suggests that she implicitly follows the Hallidayan model in that she identifies the linear arrangement with thematic structure.) The following analysis, however, finds all these strategies in Bill Johnston's English translation of the Polish short story "Przygoda Stasia" by Bolesław Prus, and further shows that they also serve to keep the ST's distribution of CD.

The short story opens with this passage:

(18) Bohaterem opowiadania jest osoba, która ma trochę więcej niż łokieć wzrostu, około trzydziestu funtów wagi i ledwie od półtora roku odbywa doczesną wędrówkę. Tę klasę obywateli kraju ludzie dorośli przezywają dziećmi i w ogóle nie traktują dość poważnie. (Prus 2003: 79)

[The hero of this story is a person who is just over an ell tall, weighs around thirty pounds and has been making the earthly pilgrimage for barely a year and a half. This class [acc. sing.] of the country's citizens adults call children and do not treat them at all seriously.]

The clause in bold begins with the direct object (te klase obywateli kraju) followed by the subject (ludzie dorośli). Both the object and the subject are thematic but the former carries more CD than the latter. Thus, ludzie dorośli is theme proper, while tę klasę obywateli kraju is diatheme. The clause-final element dziećmi is the most communicatively dynamic one and serves as rheme proper. Hence, the linear arrangement of the clause in question corresponds with the CD of its elements. ${ }^{8}$ Thus, even though the clause departs from the default Polish SVO order, it is not marked as it is in keeping with the dominant principle governing word order in Polish, i.e. the FSP linearity principle whereby sentence elements are arranged according to their growing $\mathrm{CD} .{ }^{9}$ In other words, the inverted word order of the clause is unmarked because the element in clause-initial position is thematic (cf. Firbas 1992: 125-6).

In order to render the information structure of the clause under discussion in English one might front the direct object, which would yield:

(19) This class of citizens grown-ups call children

On the face of it, the clause in bold in (18) and clause (19) have the same information structure. However, the latter has marked word order as a result of deviating from the grammatical principle whereby the position of sentence elements is determined by their syntactic function (Firbas 1992: 118; 122). ${ }^{10}$ Thus, even though (18) and (19) display the same linear arrangement and distribution of CD, they are not fully equivalent in terms of FSP, as the latter features what Firbas calls emotive word order (125). Since the word order of the Polish clause is unmarked 
and since English is not so ready to use word order for emotive purposes (134), it is just as well that the translator has not gone for (19) but has combined Baker's strategies (i) and (ii), changing the voice and the verb:

(20) The hero of this story is an individual who is just over a foot and a half tall, weighs around thirty pounds, and has been in existence for barely eighteen months. This class of citizens is known to grown-ups as children, and they are not treated at all seriously. (Johnston 1996: 1)

Rather surprisingly, the sole example of strategy (ii) provided by Baker is replacing a verb with its reciprocal equivalent (e.g. give/get, buy/sell), a translation method which corresponds to Vinay and Darbelnet's modulation of the type they call reversal of terms (Vinay and Darbelnet 1995: 251). There are, however, a number of other types of modulation which Baker fails to mention and which may be used to preserve the ST's information structure and linear arrangement. Thus, in (20), apart from changing the voice (which is also one of Vinay and Darbelnet's kinds of modulation), the translator employs a cause and effect modulation. The fact that Baker speaks of only one type of verb change explains why she has not been able to find any examples of it in actual translations, especially as it is a kind of change that tends to sound unnatural, as she herself points out (Baker 1992: 168).

The clause in bold in (20) is a felicitous translation since it begins with diatheme and ends with rheme proper just like its ST equivalent. At the same time its word order is unmarked. Hence, this version is preferable to (19) but also to (21) below, which is yielded by mere passivization:

(21) This class of citizens is called children by grown-ups, who do not treat them at all seriously.

The sentence is a little odd in terms of FSP. The immediately relevant preceding context indicates that the communication is oriented toward children rather than grown-ups. The sentence implements the Quality Scale, by ascribing to the bearer of quality (this class of citizens) the quality children. The verb called serves as a copula and performs the function of ascribing a quality (cf. Firbas 1992: 68). However, because of the subordinate clause elaborating on the thematic grownups, attention is shifted away from the quality, which somewhat thwarts the purpose of the Quality Scale. Additionally, the subordinate clause following grownups suggests the Combined Scale with grown-ups performing the function of specification. As a result, there is a conflict between the two scales vying, as it were, with each other. Thus, (20) is preferable since it avoids the tension by putting children in clause-final position, like the ST does. Placing the word in this position also gives it additional emphasis and makes it more informative than grown-ups in the sense of being "new or unexpected for the readers" (de Beaugrande and Dressler 1981: 139). This is because the rhetorical purpose of the first 
paragraph in the ST is to defamiliarize the titular child or to make the reader look at him with fresh eyes.

Baker's strategy (ii) is also to be found in the translation of this passage:

(22) „Oj! żebyś ty mnie podwiózł!...” — pomyślała kowalowa, lecz nie śmiała odezwać się do właściciela dryndulki, choć szła tuż za nią.

Biedką ową, zbudowaną tak kunsztownie, jechal pan Loski, obywatel ziemski i sędzia gminny. (Prus 2003: 97)

[If only you'd give me a lift! thought the blacksmith's wife but she did not dare to speak to the owner of the trap, though she was walking right behind it. [In] this trap [instr. sing.], built with such great craftsmanship, rode Mr. Loski, landed gentleman and district judge.]

The sentence in bold features inverted word order (adjunct-verb-subject) which is not marked, however, as the fronted element is thematic, having been mentioned in the immediately relevant context. The sentence implements the Presentation Scale as it signals the appearance on the scene of Mr. Łoski rather than predicate anything about him. Johnston translates it thus:

(23) If only you'd give me a lift! thought the blacksmith's wife, but she was too shy to speak to the owner of the trap, though she was walking right behind it.

This trap, built with such great craftsmanship, bore Mr. Loski, landed gentleman and district judge. (Johnston 1996: 32-33)

The translator skillfully preserves the FSP of the original by changing the verb. The distribution of CD is the same and so is the word order. Moreover, Johnston keeps the TT unmarked by avoiding fronting, which would have occurred if he had opted for

(24) In this trap, built with such great craftsmanship, rode Mr. Łoski, landed gentleman and district judge.

The translation of the first sentence in the second paragraph (which follows right after (18)) brings an instance of strategy (iv), i.e. extraposition:

(25) Dlatego z pewną obawą przedstawiam czytelnikom niedużego Stasia i przede wszystkim proszę ich o cierpliwość. (Prus 2003: 79) [For this reason [it is] with some trepidation [that I] present to readers little Staś and above all ask them for patience.]

Given the context of the utterance, it is clear that z pewna obawa cannot be interpreted as a thematic element, i.e. a setting, since it is this piece of information that adds 
to the previous discourse, while the elements czytelnikom and niedużego Stasia are context dependent, the former being retrievable from the situational and the latter from the verbal context. Thus, z pewna obawa carries the most CD and functions as rheme proper. (Needless to say, it also bears nuclear stress.) The word order of the clause is marked as a result of deviating from the FSP linearity principle, which is overridden here by the complementary emotive principle whereby word order conveys the speaker's emotional attitude (Firbas 1992: 120). As for the TT clause, it becomes marked and puts the equivalent of the Polish phrase $z$ pewna obawa close to sentence initial position by means of a cleft construction:

(26) For this reason, it is with a certain trepidation that I present little Staś to my readers, and above all ask them to be forbearing. (Johnston 1996: 1)

Without the cleft construction the clause in bold would read:

(27) For this reason, with a certain trepidation I present little Staś to my readers

Neither the contextual nor the semantic factor prevents linear modification from asserting itself, and thus with a certain trepidation becomes a setting, i.e. a thematic element, unlike the rhematic z pewna obawa in the ST. Interestingly, this information structure lowers the informativity of (27) to the point of making it meaningless since the fact that adults do not treat children seriously (mentioned in the previous sentence) has no logical connection to the narrator's intention of presenting Staś to his readers. It is only when with a certain trepidation becomes the most communicatively dynamic element that the connection is established, and it is the cleft construction that enables the translator to make the phrase in question the rheme proper of the whole sentence counter to linear modification (cf. Firbas 1992: 130).

Further on in the text is to be found strategy (iii), i.e. nominalization:

(28) Tymczasem nadeszło lato, a wraz $\mathrm{z}$ nim chwila, w której nadspodziewanie dobrze miały zakończyć się ojcowskie kłopoty kowala. (Prus 2003: 89)

[Meanwhile came the summer and with it the moment in which unexpectedly happily were to end the paternal problems of the blacksmith.]

The passage has been translated as follows:

(29) Meanwhile the summer came, and with it the moment in which an unexpectedly happy conclusion was to be found for the blacksmith's paternal worries. (Johnston 1996: 19) 
By nominalizing the verb zakończyć się as conclusion, the translator avoids linear dislocation, which would otherwise be inevitable due to syntactic constraints, as the ST puts the grammatical subject (ojcowskie klopoty kowala) in sentence-final position, which would be impossible in English. The ST word order is marked since nadspodziewanie dobrze is rhematic, while ojcowskie klopoty kowala is thematic, being retrievable from the immediately relevant context. The linear arrangement of the ST is preserved in the TT, but the latter's word order is not marked because nominalization arranges the clause elements in the subject-verbadjunct order and thus the grammatical principle is not violated.

The clause in bold in (29) provides an example of what Firbas (1961: 79) calls distinct relief, i.e. a high degree of conspicuousness of a sentence element over against other elements, a conspicuousness due to a marked difference in the amount of CD between them. Distinct relief stems from what he calls the dissociating process, whereby "each semantic element (no matter whether conveying grammatical or lexical meaning)" is given "its own separate form within the sentence" (81). The process results in a shift towards nominal expression, typical of English, whereby the notional content of the verb is separated from it and is expressed by a non-verbal element (83). Thus, the verb becomes purely transitional, i.e. semantically weak and low in $\mathrm{CD}$, while its notional component passes into the theme or the rheme (83). Firbas argues that nominal elements make for more concrete expression than verbal ones (90); to his mind, English "favours the expression of rhematic notions rather by nominal than by verbal elements" and "ultimately tends to render the predicative verb markedly transitional" (95). By contrast, Czech "liberally permits the predicative verb to convey rhematic notions" and "the transitional verb to move up close to the rheme" (95), which also holds true for Polish. As a result, a much more marked contrast occurs in English than in Czech (or Polish for that matter) between the amount of CD in the rhematic and non-rhematic parts of the sentence.

The phenomenon of distinct relief can be observed in the clause in bold in (29) where the verb phrase was to be found carries noticeably less CD and semantic content than the context-independent subject an unexpectedly happy conclusion. At the same time the disengaged notional component in the English version passes into the rheme, while the Polish verb phrase mialy zakończyć się carries more semantic content. As a result, the distribution of CD in (29) is subtly different than in (28). Although in principle both are perspectived toward the happy end of the blacksmith's troubles, the TT meaning is expressed in a more concrete manner with the rheme organized around the headword conclusion. This difference between the ST and the TT stems from the translator's adherence to English idiom and could hardly be considered an error on his part. On the contrary, one might even venture to say that the concreteness and distinct relief of the TT's rheme is a form of compensation for the loss of markedness. Thus, Johnston skillfully preserves the ST's distribution of CD and linear arrangement while taking account of its markedness or lack thereof. 


\section{Conclusion}

As the above discussion demonstrates, when evaluating the quality of a translation, the original's distribution of communicative dynamism (or given/new information) should be a more important consideration that its linear arrangement. The analysis of examples from Spanish into English and Polish into English translations shows that deviations from the original word order may be justified by information structure considerations, which should be taken into account before judgment is passed on the TT's thematic structure (in the SFL sense of the term).

Information structure does not feature prominently in the SFL framework, which lacks a well-developed apparatus for dealing with it. If it is discussed, it is mainly from the phonetic point of view or from one that would correspond to the contextual factor in the FSP approach. By contrast, the FSP model is better equipped to analyze information structure, positing as it does the universal category of $\mathrm{CD}$, whose distribution is reflected in the dynamic semantic scales. However, when the information structure of the ST is found to have been preserved in the TT, the analysis may go on to examine the TT's themes (in the Hallidayan sense) and this is where insights provided by SFL may prove particularly useful.

This paper also points to a hierarchy of priorities that the translator should follow when dealing with the ST's information and thematic structure. The overriding consideration is the original's distribution of $\mathrm{CD}$ which yields one of the dynamic semantic scales; the second one is either word order or markedness/ unmarkedness. It appears that in the case where the ST's word order is unmarked (as in all the Spanish examples, (1), (4), (7), (11) and (15)), it is more important to keep the TT unmarked rather than adhere to the original linear arrangement if the two are in conflict. If, by contrast, the ST is marked (as in (25) and (28)), it seems that the TT is better left unmarked if keeping it marked prevents the original word order from being preserved.

As has been shown, the strategies for avoiding linear dislocation in translation described by Baker can indeed be found in actual translations; in fact, the examples were selected from just one short story. These techniques may serve not only to preserve the ST's word order but also, at the same time, its distribution of CD and hence its dynamic semantic scale. (Sometimes, however, the Combined Scale may be translated as the Presentation Scale or vice versa, as demonstrated by (7) and (8).) Moreover, the strategies may help avoid translations that are less suitable in terms of FSP and thus to enhance the interplay between CD and the linear arrangement, as in (20).

The discussion of Johnston's translation of the Polish short story yields some more observations. Thus, (20) illustrates that strategy (ii) involves not only replacing a verb with its reciprocal equivalent, but also using an altogether different one. (29), in turn, shows that strategy (iii), i.e. nominalization, may also trigger the dissociating process and thus create the effect of distinct relief in the TT, a phenomenon which may constitute a form of compensation for the loss of marked word order. 
Munday mentions the notion of domesticating and foreignizing translation put forward by Venuti and points out that the translator of the García Márquez short story has opted for the first one, perhaps owing to some pressure from the publisher (Munday 1998: 208). This does not seem, however, the best way of looking at thematic and/or information shifts in translation. As this paper has shown, the question is not whether to discard the ST's linear arrangement or produce an awkward TT, but rather how to achieve similarity in difference. This can only be accomplished if the information structure of the ST is properly interpreted and recreated in the TT in accordance with TL rules. Undoubtedly, of great help here may be the theoretical apparatus developed by the Brno branch of the Prague School.

\section{Notes}

As Fries (1983: 117) points out, this definition "is not advanced as a language universal, but rather as a claim about English". The distinction, however, seems often overlooked in SFLbased analyses of thematic structure shifts in translations.

In this paper, the term "thematic structure" will be used in the Hallidayan sense, while "information structure" will be synonymous with "functional sentence perspective", defined by Firbas (1992: 11) as "the perspective in which a semantic and grammatical sentence structure is to function in the act of communication".

When inflectional languages, such as Polish, are described as having flexible word order, it should be borne in mind that their word order is not, strictly speaking, free or stylisticallymotivated but is determined by and reflects the distribution of CD (cf. Szwedek 2010: 47-48). Close translations of Spanish examples are Munday's.

Firbas (1992: 66-67) postulates three scales of dynamic semantic functions. The Presentation Scale consists of setting, presentation of phenomenon and phenomenon presented; the Quality Scale is implemented by setting, bearer of quality, quality, specification and further specification; the Combined Scale is comprised of setting, presentation of phenomenon, phenomenon presented, bearer of quality, quality, specification and further specification, with phenomenon presented and bearer of quality telescoped into one element followed by a distributional subfield (e.g. a clause or a semiclause). The arrangement of the elements is interpretative, not linear, and not all of them need to be implemented in each scale.

Svoboda (1983: 60) posits different degrees of CD within the thematic elements of the clause with diatheme being the most communicatively dynamic one.

In the FSP approach, this verb serves as transition, i.e. a link between the thematic and rhematic part of the sentence and as such cannot be the high point of the communication.

As has been pointed out earlier, the fact that diatheme is placed before theme proper does not change the overall theme-rheme sequence of the sentence.

This observation, made by Firbas (1992: 119) about Czech, also holds true for Polish, which is a closely related language. This is confirmed by Grzegorek (1984: 139), who argues that the main criterion of the markedness of word order in Polish is the violation of what she calls the communicative principle whereby information is ordered from old to new.

Again, the same is held by Grzegorek (1984), who claims that English word order becomes marked when it deviates from the SVO order. Speaking of English and Polish word orders, she observes that the former has "primarily a grammatical function" (139) unlike the latter, which "is essentially governed by the principles of functional sentence perspective" (138-139). 


\section{References}

Baker, Mona (1994) In Other Words: A Coursebook on Translation. London: Routledge.

Beaugrande, Robert de and Wolfgang Dressler (1981) Introduction to Text Linguistics. London and New York: Longman.

Daneš, František (1974) Functional Sentence Perspective and the organization of the text. In: Daneš, František (ed.) Papers on Functional Sentence Perspective. Prague: Academia, 106-128.

Firbas, Jan (1961) On the communicative value of the modern English finite verb. Brno Studies in English 3, 79-101.

Firbas, Jan (1966) Non-thematic subjects in contemporary English. In: Vachek, Josef (ed.) Travaux linguistiques de Prague, vol. 2. Prague: Academia, 239-256.

Firbas, Jan (1979) A functional view of “ordo naturalis". Brno Studies in English 13, 29-59.

Firbas, Jan (1992) Functional Sentence Perspective in Written and Spoken Communication. Cambridge: Cambridge University Press.

Fries, Peter H. (1983) On the status of theme in English: arguments from discourse. In: Petöfi, János S., and Sözer, Emel (eds.) Micro and Macro Connexity of Texts. Hamburg: Helmut Buske.

Grzegorek, Maria (1984) Thematization in English and Polish: A Study in Word Order. Poznań: Wydawnictwo Naukowe im. A. Mickiewicza.

Halliday, Michael A. K. (1994) An Introduction to Functional Grammar. London: Edward Arnold. Johnston, Bill (1996) Staś's Little Adventure. By Prus, Bolesław. In: The Sins of Childhood and Other Stories. Evanston, Illinois: Northwestern University Press, 1-50.

Kim, Mira and Christian M. I. M. Mathiessen (2015) Ways to move forward in translation studies: A textual perspective. Target 27 (3), 335-350.

Munday, Jeremy (1998) Problems of applying thematic analysis to translation between Spanish and English. Cadernos de traducão 1(3), 183-213.

Prus, Bolesław (2003 [1899]) Przygoda Stasia. In: Wybór nowel. Kraków: Wydawnictwo GREG, 79-108.

Svoboda, Aleš (1983) Thematic elements. Brno Studies in English 15, 49-85.

Szwedek, Aleksander (2010) The Thematic Structure of the Sentence in English and Polish. Łódź and Warszawa: SWSPiZ.

Vinay, Jean-Paul and Jean Darbelnet (1995) Comparative Stylistics of English and French. Trans. Sager, Juan C. and M.-J. Hamel. Amsterdam and Philadelphia: John Benjamins.

MaCiEJ Reda works at the Warsaw School of Applied Linguistics where he teaches translation classes. His main research interest is the relationship between translation and Functional Sentence Perspective. He is a translator himself and has translated, among others, six books by G. K. Chesterton into Polish.

Address: Dr. Maciej Reda, Warsaw School of Applied Linguistics, Atrium Reduta Business Center, Al. Jerozolimskie 148, 02-326 Warsaw, Poland. [maciej.reda@gmail.com] 